\title{
Technology Readiness and Users Satisfaction towards Self-Service Technology at Malaysian Airport
}

\author{
Nik Ab Halim Nik Abdullah \\ School of International Studies, Universiti Utara Malaysia \\ abhalim@uum.edu.my
}

\begin{abstract}
This study examines the relationship between four dimensions of Technology Readiness Index (TR) namely optimism, innovativeness, insecurity, discomfort, and the level of customer's satisfaction towards the use of self-service technology (SSTs) at the airport. SSTs used by the airport operators or airlines at the terminal for check-in or when performing other transactions includes booking airline ticket online, kiosk check-in and mobile check-in. At the same time, this study also tries to look at whether there is any difference in technology readiness between different demographic groups of Malaysians. Survey questionnaires were distributed to passengers at Kuala Lumpur International Airport (KLIA) and Low Cost Carrier Terminal (LCCT) in Sepang, Selangor, Malaysia. The result of the analysis shows that innovativeness and optimism have a positive relationship with customer satisfaction. There are also differences in technology readiness among different gender for innovativeness and insecurity index. The implication of the study suggests that Malaysia's airport or airline providers should increase customer satisfaction especially by introducing new innovative technology at their premises. The findings may also help firms develop their strategy to further increase the customer's satisfaction when using the selfservice technology (SST) at airports in Malaysia.
\end{abstract}

Keyword: Technology Readiness Index (TRI), Airport Self Service Technology (SST), Customer Satisfaction

\section{Introduction}

The airline industry these days are under huge pressure to reduce costs of operations due to increase in fuel price, economic downturn and the escalating threat of terrorism since the 9/11 attack in New York. As a result, airlines are forced to reduce the operating costs and at the same time improve their service efficiency through the introduction of Self service technologies (SST) (Ito \& Lee, 2005). Airport SST consists of many sub-systems that helps passengers take the necessary action by themselves without the assistance of a service providing employee. Among the system currently adopted in many airports according to Abdelaziz et al. (2010), includes:

○ Information kiosk, which is a standalone terminal that provides information, goods and services.

○ Ticketing kiosk, which is a place where passengers may purchase airline tickets, check baggage and monitor flight status.

- Common Use Self Service (CUSS) kiosk, which is a shared terminals with multiple airlines that helps ease congestion and reduce long lines.

- Retail kiosk, where customers can purchase goods and services before or after a flight

$\circ \quad$ Internet bookings and through the use of smart phones or mobile devices.

Air passengers these days are encouraged to use SST and Malaysian travellers are experiencing the same situation, as SST is widely used at most major airports in the country. The customers of Malaysia Airlines Berhad (MAS) for example can book, pay, check-in and search for hot deals via the MHkiosk, which is a system, equipped with iPad. Customers can also check flight schedules and status, choose their preferred seats and check the status of lost baggage through the five self-service iPad kiosks which uses the MHMobile interface (Kollau, 2011). Similarly, Air Asia, the "World's Best Low-Cost Airline" has revolutionised the aviation industry with the inclusion of its web and self check-in service. These new self check-in kiosk facilities are currently located at the Low Cost Carrier Terminal (LCCT) airport and selected regional airports, providing guests with a quicker and more convenient way of checking-in. For both comfort and convenience, guests could also utilise Air Asia's web-based check-in service. It is expected to avoid airport congestions, long queues and reduce waiting time. The customers can check-in using the quick and easy to use self check-in kiosks at the airport or through online and print their own boarding pass. Customers may check-in 48 hours prior and up to 4 hours before the scheduled departure time online ("AirAsia", 2010). CUSS was introduced at the Kuala Lumpur International Airport (KLIA) 
since 2007 and there are currently five airlines using CUSS - Malaysia Airlines, Air Asia, KLM Royal Dutch, Thai International and Cathay Pacific Airways. As of 2009, $9 \%$ of departing passengers use CUSS facilities, in the region of 62,000 passengers per month. The implementation of Bar Code Boarding Pass (BCBP) and CUSS at the airport were benefiting the passengers to enjoy hassle free check-in. Passengers nowadays also have the options to check-in at home using their mobile devices. A bar code will be sent to a mobile phone as electronic boarding passes. Passengers may also print their boarding pass at the kiosk. International Air Travel Association (IATA) predicts a cost savings of up to US $\$ 1.5$ billion every year for the industry due to the implementation of BCBP. IATA has mandated that by the end of 2010, all airlines must use BCBP ("Malaysia Airports To Host Another High Profile Aviation Forum," 2010).

Currently, the ratio between traditional counter check-in and online check-in in KLIA According to Malaysia Airports Holdings Bhd (MAHB) managing director Tan Sri Bashir Ahmad is 70:30. The number of online check-in however is expected to increase once the new low-cost carrier terminal, or KLIA2, which will be operational by mid-2012, aims to gradually move away from traditional check-in and conduct more web-based check-in services ("KLIA2", 2012). The success of new technology adoption such as SST is impacted by the readiness of the user in embracing the technology. Based on the above scenario where the use of SST is expected to increase in the future, this study is conducted to find out the relationship between technology readiness index and customer satisfaction, and do demographic factors influence technology readiness level. The specific purpose of this study is to identify whether customers are satisfied or not with the self-service technology used at Malaysia airport. In addition, the findings hopefully will enable service firms to alter their marketing strategies in order to increase the adoption rates among each different demographic segment of customers. At the same time, this study may help boost customer satisfaction through the improvement of service by the airline company itself. The findings are expected to provide some insight and information on how the airline industry can improve their strategy to retain and satisfy their customers based on TR dimension. Highly satisfied air passengers are important for airline companies because loyal customers that keep on using their services are the principal driver for profits. Therefore, this study will make the airline companies aware on which TR dimensions influence the customer tendency to use SST and their level of satisfaction when using it. Airlines can focus and put double effort to improve their services based on the identified TR dimensions.

\section{Literature Review}

The term technology-readiness refers to people's propensity to embrace and use new technologies for accomplishing goals in home life and at work (Parasuraman, 2000). Empirical studies suggesting that people's beliefs about technology have both positive and negative facets, and can be categorized into four distinct technology readiness dimensions, namely, optimism, innovativeness, discomfort, and insecurity (Parasuraman \& Colby, 2001). Past study has found that the innovativeness and optimism have a positive relation with the users' readiness while discomfort and insecurity gave a negative relation to the users (Radzatul et al., 2009). Optimism refers to a positive view of technology and a belief that it offers people increased control, flexibility, and efficiency in their lives (Parasuraman \& Colby, 2001). Innovativeness is a tendency to be a technology pioneer and thought leader. Innovativeness measures the extent to which an individual believes he or she is at the forefront of trying out new technology based products and/or services and is considered by others as an opinion leader on technology-related issues (Parasuraman \& Colby, 2001). Individual with high optimism and innovativeness is expected to have stronger intrinsic motivation to use the new technology and enjoy the stimulation trying new technology, hence result in customer satisfaction. Innovativeness according to Putit (2008) is consumer predisposition to adopt online transaction behaviours earlier then rest of his/her social system. Individual with high innovativeness have stronger intrinsic motivation to use the new technology and enjoy the stimulation trying new technology. Previous studies indicate that innovativeness have a strong positive effect on behavioral intention to use technology related product or service such as IT-based innovation (Yi, Fiedler, \& Park, 2006), mobile data service (Yang, 2010) and webcasting (Lin, 2004). Hence, it is hypothesised that innovativeness positively affect customer's satisfaction when using airport SST. Discomfort is a perceived lack of control over technology and a feeling of being overwhelmed by it (Parasuraman, 2000). This represents the extent to which people have a general paranoia about technology-based products and services, believing that they tend to be exclusionary rather than inclusive for all kinds of people (Tsikriktsis, 2004).

In the context of SST, discomfort passengers might need a proper guidance when using SSTs since the process may trigger frustration especially when passengers have to confront a complicated devices or 
procedures (Putit, 2008). Insecurity on the other hand is the feeling of distrust of technology and scepticism about its ability to work properly. Although somewhat related to discomfort, this dimension focuses on specific aspects of technology-based transactions, rather than on a lack of comfort with technology in general (Tsikriktsis, 2004). Feeling of insecurity might result in people's resistance towards the use of technology such as rejection, postponement and opposition that will effect business operation. Consumers might also distance themselves if they have a negative view towards the technology and assumes that the innovation might be harmful, unhealthy or might cause injury (Kleijnena, Leeb, \& Wetzelsc 2009). Insecurity is the result of lack of trust in technology and its ability to work properly. A perceived lack of security towards the SST system will resulted in slower rate of adoption among consumers (Parasuraman, 2000). Consumers might resist innovation and display a negative behaviour such as rejection, postponement or even opposition if they assume that the innovation might be harmful, unhealthy or might cause injury (Kleijnen et al., 2009). In the context of this study insecurity is a negative emotions that trigger negative behaviours, which might obstruct customers from using SST when performing their check-in. Therefore, it is expected that insecurity will have a negative relationship with customer satisfaction. Customer satisfaction is an emotional reaction after consumers purchase and experience a product or service (Shih-Chih, 2011). These accumulative reactions have become the customer satisfaction with a company. Customer satisfaction is based on an evaluation of product-related standards, product consumption experiences and or purchase-related attributes (Giese \& Cote, 2002). To ensure customer is satisfies with the services, the companies need to achieve quality not only by eliminating the cause for direct complaint but they need provide their product or services with excellent, attractive quality and provide the delight to the customers (Feciková, 2004). Apart from that, consumer satisfaction is derived from the customers' comparison of their actual experience with a service and contrasted with the customers' service expectation (Gilbert \& Veloutsou, 2006). This study infers that customer satisfaction levels are positively affected by the two contributors of technology readiness, which is optimism and innovativeness whereas discomfort and insecurity are inhibitors that negatively influence customer's satisfaction towards the use of self-service technology.

There are studies such as by Jiun-Sheng and Hsing-Chi (2011), Marzocchi and Zammit (2006) and Meuter et al. (2003) that look at the influence of various factors on customer satisfaction with SST in general or in various type of technology adoption, but specific research on airport SST did not gain much attention. Some study on airport SST such as by Abdelaziz et al. (2010) use case study method to answer the research questions. Their study also did not look at technology readiness as an influencing factor. Therefore, an empirical research that looks at the impact of technology readiness on SST adoption is needed to give more understanding on this matter. In addition, previous study also did not study the impact of TRI on customer satisfaction when using airport SST, although customer satisfaction could results in higher customer loyalty, higher willingness to repurchase, higher profits and higher market share for companies. Based on the above discussions on some gap identified in the literature, this paper will focus on the relationship between Technology readiness and customer satisfaction towards the use of SSTs at Malaysian airport. At the same time, it looks at the influence of demographic factor towards Technology Readiness and satisfaction. Therefore, the objective of this paper is to answer the following research questions:

- Is there any correlation between the four TRI components and customer satisfaction in using the SSTs at Malaysian airport?

- Is there any difference in TRI between different demographic characteristics (gender, age, education) of consumers?

\section{Methodology}

A quantitative research design with survey method was used for data collection. The survey questionnaire was developed based on the Technology Readiness Index (TRI) introduced by (Parasuraman, 2000). TRI is a multiple-item scale developed to measure consumers' readiness to embrace new technologies. The questionnaire consists of three sections namely section A, B and C. Section A represents the check-in information of each respondent such as types of self-service systems used, name of airline and locations where the self-service activities performed. Section B tries to obtain the demographic information of the respondent Section $C$ consists of questions related to both the independent and dependent variables. It is made of 25 questions. The original items in TRI were customised to reflect the purpose of this study, which is on airport SST. A 5 point Likert Scale is used to measure the four (4) dimensions of TR and customer satisfaction of using the SST (1 = strongly disagree, 5 strongly agree). The population for this study are all air passengers who travel inbound and outbound 
at KLIA and LCCT, and use the airport SST available especially during check-in. It includes those who use kiosk check-in, online check-in and mobile check-in. KLIA handles 37,704,510 air passengers in the year of 2011 ("Kuala Lumpur International Airports - Achievement," 2012) while LCCT handles about 17 million air passengers per annum ("KLIA2 to open October 2012," 2012). Apparently, the number of total passengers using KLIA and LCCT daily is about 132,000 passengers. The sampling technique used in this study is purposive sampling. According to Sekaran (2003), purposive sampling is a non-probability sampling design in which information or data for the research are gathered from members of the population who can provide the desired information, because they are the only one that fulfil the criteria set by the researcher. In this case, only passengers who use SST system during check-in were randomly selected because the focus of this study is on customer's satisfaction among those who use the SST only. Based on the above number of passengers, the required sample size according to Sekaran (2003) is about 383 samples. The actual survey questionnaires were self distributed and collected by the researchers. Respondents are required to fill in the questionnaire by themselves, without any interference from the researcher. However, only 200 surveys were distributed because the airport authority only allows the data collection at both airports for 2 days only. All 200 questionnaires were collected back from the selected passengers. The Statistical Package in the Social Science Software (SPSS) versions 17 were used to conduct data analysis after the questionnaire have been collected from the respondents. Descriptive statistics especially the mean and percentages are used to describe the demographic profile of the respondents. T-test, one-way analysis of variance (One way ANOVA), correlation and multiple regressions were used to answer the research questions of the study.

\section{Research Results}

Reliability analysis: Table 1 shows the results of reliability analysis of the measuring instrument.

Table 1: Cronbach Alpha value

\begin{tabular}{ll}
\hline Variable & Cronbach Alpha \\
\hline Optimism & 0.872 \\
Innovativeness & 0.691 \\
Discomfort & 0.516 \\
Insecurity & 0.697 \\
Customer satisfaction & 0.860 \\
\hline
\end{tabular}

The Cronbach's alpha coefficient for all variables exceeded the minimum value, which is 0.60 (Peterson, 1994) except for discomfort (0.516). Probably the small number of items to measure discomfort (only 4 items) resulted in these "relative moderate coefficients". Indeed, it has been shown that Cronbach's alpha estimation of reliability increases with scale length (i.e. number of items in the scale) (Cronbach, 1951); (Voss, Stem, \& Fotopoulos, 2000). Therefore, discomfort is still included in the data analysis.

Demographic: Table 2 shows the demographic profile of the respondent. Out of the 200 respondents, $60.5 \%$ or 121 were male and $39.5 \%$ or 79 were female. Those within the age of 21 to 30 are the highest with $46 \%$ or 92 respondents, followed by 31 to 40 years of age with $34 \% .13 \%$ were 41 to 50 years old, $12.5 \%$ were less than 20 years old and finally $11.5 \%$ were over 50 years old. In terms of education, majority of the respondents or 101 of them held an undergraduate degree (bachelor degree or diploma) with $50.5 \%$, while $36 \%$ completed high school or below. Finally, $13.5 \%$ held a postgraduate degree (masters or PhD).

Correlation: In order to answer the first research question, a Pearson Correlation analysis was conducted and the output is shown in table 3. There was a positive and significant correlation between innovativeness and optimism on customer satisfaction when using the self-service technology at the airport. In contrast, discomfort and insecurity did not significantly influence satisfaction. According to Sekaran (Sekaran, 2003), correlation score of 0.7 and above can be interpreted as having a very strong relationship, 0.5 to 0.69 score considered as having a strong relationship, 0.3 to 0.49 as moderate, 0.1 to 0.29 as having a low relationship and lastly 0.01 to 0.09 deem to have very low relationship.

Demographic profile and technology readiness: The second research question tries to look at whether there is a significance differences in technology readiness about SST among various demographic factors of the respondents. T-test and analysis of variance (ANNOVA) were conducted to answer the research question. Result of the analysis is indicated in table 4. 
Table 2: Demographic profile of the respondent

\begin{tabular}{lll}
\hline Variable & Frequency & Percentage \\
\hline Gender & & \\
Male & 121 & 60.5 \\
Female & 79 & 39.5 \\
Age & & \\
Less than 20 & 25 & 12.5 \\
21 to 30 & 92 & 46.0 \\
31 to 40 & 34 & 17.0 \\
41 to 50 & 26 & 13.0 \\
More than 50 & 23 & 11.5 \\
Education & & \\
High school or below & 72 & 36.0 \\
Undergraduate & 101 & 50.5 \\
Postgraduate & 27 & 13.5 \\
\hline
\end{tabular}

Table 3: Pearson's correlation between 4 TRI and customer satisfaction

\begin{tabular}{llll}
\hline & Satisfaction & Sig. (2 Tailed) & Strength \\
\hline Optimism & $0.300^{* *}$ & .000 & Moderate \\
Innovativeness & $0.450^{* *}$ & .000 & Moderate \\
Discomfort & -0.98 & .167 & \\
Insecurity & 0.92 & .197 & \\
\hline
\end{tabular}

Note: Significant at 0.01 levels.

Table 4: Demographic profile and technology readiness

\begin{tabular}{lllllll}
\hline TRI & Gender & \multicolumn{3}{c}{ Age } & \multicolumn{3}{c}{ Education } \\
\hline \multirow{2}{*}{ Optimism } & $\mathbf{t}$ value & Sig. & F value & Sig. & F value & Sig. \\
\cline { 2 - 7 } Innovativeness & .710 & .478 & .414 & .798 & 1.566 & .212 \\
Discomfort & .614 & $.017^{*}$ & .300 & .878 & 1.333 & .266 \\
Insecurity & -2.059 & .540 & .661 & .619 & .442 & .643 \\
\hline
\end{tabular}

Note: $* p<0.05$

The ANNOVA output clearly indicates that there is no significant difference in optimism, innovativeness, and discomfort and insecurity index between respondent from different age group and from different level of education. However, there is a statistically significant differences observed between different gender group for two out of four technology readiness index, namely innovativeness and insecurity. The mean value for innovatiness is 3.81 for male and 3.58 for female. It shows that male respondent relatively more ready to use innovative product than female. For insecurity, mean value for male is 3.28 while female is 3.50. Therefore, it can be said that Malaysian female users feel more insecure than man does when using new technology.

Discussion: The first research question try to seek out whether there is any correlation between the four TRI components and customer satisfaction in using the SSTs at Malaysian airport. Findings indicate that two-technology readiness index namely optimism and innovativeness were significantly correlated with satisfaction. It shows that Malaysians are optimistic when it comes to new technology adoption and the usage of it will create satisfaction and positive attitude of towards technology. Even the Nielsen Global Online Survey (2011) indicates that $28 \%$ of Malaysians spent more money on new technology products rather than clothes, retirement fund, home entertainment or home decoration in the first quarter of 2011. They are always optimistic about new technology and generally have positive feelings towards such technology. The finding is also similar with previous studies that have also found out that optimism is important in improving service quality, enhancing satisfaction and behavioural intentions toward SST 
(Lin \& Hsieh, 2006; Lanseng \& Andreassen, 2007). For innovativeness, this result is in line with previous findings whereby innovativeness is found to have a positive effect on the satisfaction level of new technology usage (Nemati, Khan, \& Iftikhar, 2012; Jong, Ruyter, \& Lemmink, 2003). Malaysians in fact are known for their enthusiasm towards new technology and tech savvy. This can be observed from the level of penetration for the latest information and communication technology product or gadget such as smart mobile phone technology like iPhone and Blackberry, tablet, Global Positioning System (GPS) and so on. A recent study said that tablet sales in the country reached over 260,000 units in the fourth quarter of 2011, a 509 percent growth compared to the same period in 2010. The value of the tablet market also grew "substantially" to US $\$ 140$ million in fourth-quarter 2011 from US\$4 million during the last quarter of 2010 (Qing, 2012). AC Nielsen reveals that growth of Smart phone users in Malaysia is almost doubles every year. Out of $58 \%$ of Malaysian mobile users surveyed who are likely to upgrade their phones in the next six months, four in five (79\%) plan to buy a smart phone (Singh, 2012). These studies attest that Malaysians are always interested in innovative new product and are not afraid to try it. This explains why the innovativeness factor of self-service technology at Malaysian airport results in customer satisfaction.

As expected, findings on discomfort and insecurity factors did not influence customer satisfaction. In fact, this study reveals that Malaysians do not feel discomfort when performing check-in using SST and are willing to use the website, kiosk, mobile check in or other SST facility. Furthermore, Malaysians are optimistic and like to use an innovative new technology. Even though there is a feeling of discomfort, it will not have a big impact on their satisfaction because it is overcome by the feeling of joy when using the new technology. A study by Matthing et al. (2006) supports this finding where they reveals that customers who love to adopt new technology have strong propensity to seek out new technology and enjoy tackling problem associated with it. The second research question looks if there is any difference in TRI between different demographic characteristics (gender, age, education) of consumers. From gender perspective, there is significant different in innovativeness and insecurity index between male and female Malaysians. According to the t-test results for the innovativeness factor, male respondent tend to accept innovative new technology such as airport SST more than female. There is no common agreement in previous studies on the impact of gender on technology adoption. Some studies demonstrate that there are no differences between different gender and technology adoption (Yusuf \& Balogun, 2011; Sarfo, Amartei, Adentwi, \& Brefo, 2011). The finding of this study however is similar to Venkatesh, Morris and Ackerman (2000) investigation on the determinants of technology adoption and usage behaviour, where the finding shows that the attitude toward using technology was more salient to men. Latest studies such as by Bassi and Camble (2011) on the use of library electronic resources also demonstrate similar finding. For insecurity, female feels more insecure than male when using the SST. This is similar with previous study which denotes that males are more interested in computers and related technologies than are females and have more self-confidence in working with computers (Shashaani, 1997). There is no significant different in each technology readiness index between Malaysians from different age and educational background. This is an interesting finding as previous study highlighted that age influences technology adoption and usage level (Morris \& Venkatesh, 2000; Czaja et al., 2006). Even elder users in Malaysia seems to be able to accept and use new technology comfortably as compared to previous study by Schumacher and Morahan-Martin (2001) which reveals that elder users are less comfortable and/or competent with computers and related technologies. For educational factors, a study by Mastura et al. (M2007) who study technology readiness among managers of construction firms and Ramayah et al. (2003) who study owners/managers of small medium enterprise (SME) reveals that education plays an important contribution to the TRI. Both studies designate that respondents with a degree are higher on technology readiness compared to other groups. In contrast, this study on Malaysians shows that different level of education did not influence technology readiness towards the self-service technology at the airport.

\section{Conclusion}

Introduction of self-service technology at the Malaysian airport is one of the measures taken by the airport and airlines in order to improve their service and increase customer satisfaction. This study has shown that Malaysian air passengers are indeed feeling very optimistic and have no problem at all in adopting this system, because using innovative technology actually helps improve their satisfaction. Results have also highlighted that different age and education level group have no influence at all on the level of technology readiness about SST at the airport. The only different exists is between gender group as males tend to be better prepared in using innovative technology and even feel less insecure compared to the females. As a conclusion, this study reveals that customer's optimism and the innovativeness of the SST at the airport will influence their satisfaction. Therefore, airport authorities and airline companies 
should encourage the use of SST by strengthening the positive TR drivers (optimism and innovativeness) as it creates positive attitudes toward the technology. At the same time, they should try to reduce the TR inhibitors (discomfort and insecurity) to increase the rate of SST usage. Some limitations of this study create the opportunity for improvement in future studies. First, the small number of sample size and the fact that this study was conducted at two airports only (KLCC and LCCT). Future study that involves passengers from more airports around Malaysia may help the generalisation of the findings. Expansion of the scope of the study into other countries may allow comparison between the levels of technology readiness index towards SST among people in different countries. Finally, previous study conducted in Malaysia such as by Mastura et al. (2007) and Ramayah et al. (2003) demonstrate a different finding from this study. This raise a question on whether the level of technology readiness among Malaysians depends on the type of technology studied. At the same time, there is also a possibility for future research to find out whether what kind of job people do might have difference influence on TRI or not.

\section{References}

AirAsia. (2010). Airasia Launches New Check-In Kiosk Facilities. Borneo Post, from http://www.theborneopost.com/2010/01/21/airasia-launches-new-check-in-kiosk-facilities/

KLIA2. (2012, February 09). KLIA2 to Feature More Self-Service Options, The New Straits Times. Retrieved from http://www.btimes.com.my/Current_News/BTIMES/articles/bashh

Abdelaziz, S. G., Hegazy, A. A. \& Elabbassy, A. (2010). Study of Airport Self-Service Technology Within Experimental Reseach of Check-In Techniques. International Journal of Computer Science, 7(3).

Bassi, M. D. \& Camble, E. (2011). Gender Differences in Use of Electronic Resources in University Libraries of Adamawa State, Nigeria. Library Philosophy and Practice (e-journal). Retrieved from http://digitalcommons.unl.edu/libphilprac/549

Cronbach, L. J. ( 1951). Coefficient Alpha and the Internal Structure of Tests. Psychometrika, 16, 297-334.

Czaja, S. J., Charness, N., Fisk, A. D., Hertzog, C., Nair, S. N., Rogers, W. A. \& Sharit, J. (2006). Factors Predicting the Use of Technology: Findings From the Center for Research and Education on Aging and Technology Enhancement (CREATE). Psychol Aging, 21(2), 333-352. .

Feciková, I. (2004). An Index Method for Measurement ff Customer Satisfaction. The TQM Magazine, 16(1), 57 - 66.

Giese, J. L. \& Cote, J. A. (2002). Defining Consumer Satisfaction. Academy of Marketing Science Review, 2000(1).

Gilbert, G. R. \& Veloutsou, C. (2006). A Cross-Industry Comparison of Customer Satisfaction. Journal of Services Marketing, 20(5), 298 - 308.

Ito, H. \& Lee, D. ( 2005). Assessing the Impact of the September 11 Terrorist Attacks on U.S. Airline Demand. Journal of Economics and Business, 57(1), 75-95.

Jiun-Sheng, C. L. \& Hsing-Chi, C. (2011). The Role of Technology Readiness in Self-service Technology Acceptance. Managing Service Quality, 21(4), 424 - 444.

Jong, A. D., Ruyter, K. D. \& Lemmink, J. (2003). The Adoption of Information Technology in Self-Managing Service Teams. Journal of Service Research, 6(2), 162-179.

Kleijnena, M., Leeb, N. \& Wetzelsc , M. (2009). An Exploration of Consumer Resistance to Innovation and its Antecedents. Journal of Economic Psychology, 30(3), 344-357.

KLIA2 to open October 2012. (2012). Retrieved 29 August, 2012, from http://klia2.org/News/2011/KLIA2_to_open_October_2012.htm

Kollau, R. (2011). 11 Ways Airlines are Deploying the Apple iPad. Retrieved July 29, 2012, from http://www.airlinetrends.com/2011/08/08/10-ways-how-airlines-are-deploying-the-apple-ipad/

Kuala Lumpur International Airports - Achievement. (2012). Retrieved 29 August, 2012, from http://www.malaysiaairports.com.my/index.php/international.html

Lanseng, E. J. \& Andreassen, T. W. (2007). Electronic Healthcare: A Study of People's Readiness and Attitude Toward Performing Self-diagnosis. International Journal of Service Industry Management, $18(4), 394-417$.

Lin, C. A. (2004). Webcasting Adoption: Technology Fluidity, User Innovativeness, and Media Substitution. Journal of Broadcasting \& Electronic Media, 48(3), 446-465.

Lin, J. S. C. \& Hsieh, P. L. (2006). The Role of Technology Readiness in Customers' Perception and Adoption of Self-service Technologies. Int. Journal of Service Industry Management, 17(5), 497 - 517.

Malaysia Airports To Host Another High Profile Aviation Forum. (2010). Retrieved July 29, 2012, from http://www.malaysiaairports.com.my/index.php/news-archieve/year-2010/299.html

Marzocchi, G. L. \& Zammit, A. (2006). Self-scanning Technologies in Retail: Determinants of Adoption. Service Industries Journal, 26(6), 651-669. 
Mastura, J., Ramayah, T., Abdul-Rashid, A. A. \& Basri, S. (2007). Technology Readiness Among Managers of Malaysian Construction Firms. Engineering, Construction and Architectural Management, 14(2), 180 - 191.

Matthing, J., Kristensson, P., Gustafsson, A. \& Parasuraman, A. (2006). Developing Successful Technologybased Services: The Issue of Identifying and Involving Innovative Users. Journal of Services Marketing, 20(5), 288-297.

Meuter, M. L., Ostrom, A. L., Bitner, M. J. \& Roundtree, R. I. (2003). The Influence of Technology Anxiety on Consumer Use and Experiences With Self-Service Technologies. Journal of Business Research, 56(11), 899-906.

Morris, M. G. \& Venkatesh, V. (2000). Age Differences in Technology Adoption Decisions: Implications for a Changing Workplace. Personnel Psychology, 53(2), 375-403.

Nemati, A. R., Khan, K. \& Iftikhar, M. (2012). Impact of Innovation on Customer Satisfaction and Brand Loyalty, a Study of Mobile Phones Users in Pakistan. European Journal of Social Sciences, 16(2), 299-306.

Nielsen: Consumer Confidence Stabilised. (2011). Retrieved 30 August, 2012, from http://marketinginteractive.com/news/26546

Parasuraman, A. (2000). Perception of Self-service Index (TRI): A Multiple-item Scale to Measure Readiness to Embrace New Technologies. Journal of Service Research, 2(4), 307-321.

Parasuraman, A. \& Colby, C. L. (2001). Techno-ready Marketing: How and Why Your Customers Adopt Technology. New York: Free Press.

Peterson, R. A. (1994). A Meta-analysis of Cronbach's Coefficient Alpha. Journal of Consumer Research, 21, 381-391.

Putit, L. (2008). Consumer's E-transaction Behaviour Adoption: An Exploratory Study. Journal of Human Capital Development, 1(1), 43-45.

Qing, L. Y. (2012). Malaysia's Tablet Market Grows Five-Fold, from http://www.zdnet.com/malaysiastablet-market-grows-five-fold-2062304243/

Ramayah, T., Jantan, M., Mohd. Roslin, R. \& Siron, R. (2003). Technology Readiness of Owners/managers of SMEs. The International Journal of Knowledge, Culture and Change Management, 3, 475-486.

Sarfo, F. K., Amartei, A. M., Adentwi, K. I. \& Brefo, C. (2011). Technology and Gender Equity: Rural and Urban Students' Attitudes Towards Information and Communication Technology. Journal of Media and Communication Studies, 3(6), 221-230.

Schumacher, P. \& Morahan-Martin, J. (2001). Gender, Internet and Computer Attitudes and Experiences. Computers in Human Behavior, 17(1), 95-110.

Sekaran, U. (2003). Research Methods for Business: A Skill Building Approach (4 ed.). New York: John Wiley \& Sons.

Shashaani, l. (1997). Gender Differences in Computer Attitudes and Use Among College Students. Journal of Educational Computing Research, 16(1), 37-51.

Shih-Chih, C. (2011). Understanding the Effects of Technology Readiness, Satisfaction and Electronic Word-of-mouth on Loyalty in 3C Produts. Australian Journal of Business \& Management Research, 1(3), 1-9.

Singh, K. (2012). Interesting Insights into Smartphone Behavior, from http://www.digitalnewsasia.com/node/107

Tsikriktsis, N. (2004). A Technology Readiness-based Taxonomy of customers: A Replication and Extension. Journal of Service Research, 7(1), 42-52.

Venkatesh, V., Morris, M. G. \& Ackerman, P. L. (2000). A Longitudinal Field Investigation of Gender Differences in Individual Technology Adoption Decision-making Processes. Organizational Behavior and Human Decision Processes, 83(1), 33-60.

Voss, K. E., Stem, D. E. \& Fotopoulos, S. (2000). A Comment on the Relationship Between Coefficient Alpha and Scale Characteristics. Marketing Letters, 11(2), 177-191.

Yang, K. (2010). The Effects of Technology Self-Efficacy and Innovativeness on Consumer Mobile Data Service Adoption between American and Korean Consumers. Journal of International Consumer Marketing, 22(2), 117-127.

Yi, M. Y., Fiedler, K. D. \& Park, J. S. (2006). Understanding the Role of Individual Innovativeness in the Acceptance of IT-Based Innovations: Comparative Analyses of Models and Measures. Decision Sciences, 37(3), 393-426.

Yusuf, M. O. \& Balogun, M. R. (2011). Student-Teachers' Competence and Attitude towards Information and Communication Technology: A Case Study in a Nigerian University. Contemporary Educational Technology, 2(1), 18-36. 